\title{
Acute motor-sensory axonal polyneuropathy variant of Guillain-Barre syndrome complicating the recovery phase of coronavirus disease 2019 infection: a case report
}

\author{
Ahmed Maseh Haidary ${ }^{{ }^{*}} \mathbb{0}$, Sarah Noor ${ }^{2}$, Esmatullah Hamed ${ }^{3}$, Tawab Baryali ${ }^{4}$, Soma Rahmani ${ }^{1}$, \\ Maryam Ahmad ${ }^{1}$, Farahnaz Erfani ${ }^{1}$, Hashmatullah Azimi ${ }^{1}$, Habib UI Rahman Habib ${ }^{3}$, Gul Ahmad Tahiri \\ Ramin Saadaat ${ }^{1}$, Abdul Sami Ibrahimkhil ${ }^{1}$, Esmatullah Esmat ${ }^{1}$ and Haider Ali Malakzai ${ }^{1}$
}

\begin{abstract}
Introduction: The novel coronavirus, since its first identification in China, in December 2019, has shown remarkable heterogeneity in its clinical behavior. It has affected humans on every continent. Clinically, it has affected every organ system. The outcome has also been variable, with most of the older patients showing grave outcomes as compared with the younger individuals. Here we present a rare and severe variant of Guillain-Barre syndrome that complicated the disease in recovery phase.

Case presentation: A 60-year-old Afghan man, who had been recovering from symptoms related to novel coronavirus associated disease, presented with sudden onset of progressive muscle weakness and oxygen desaturation. Electrophysiological workup confirmed the diagnosis of Guillain-Barre syndrome, and early institution of intravenous immunoglobulin resulted in complete resolution.

Conclusion: Guillain-Barre syndrome has recently been reported in many patients diagnosed with novel coronavirus associated disease. While clinical suspicion is mandatory to guide towards an effective diagnostic workup, early diagnosis of this complication and timely institution of therapeutic interventions are indispensable and lifesaving.
\end{abstract}

Keywords: AMSAN, GBS, Recovery phase, COVID-19

\section{Introduction}

Severe acute respiratory syndrome coronavirus 2 (SARSCoV-2), which originated in Wuhan, Hubei Province, China in December 2019, has now become a global pandemic, devastating every corner of the world [1]. Almost every country in the world has been affected by the socioeconomic impact of the disease [2]. Many countries

*Correspondence: ahmedmaseh.haidary@fmic.org.af

1 Department of Pathology and Laboratory Medicine, French medical Institute for Mothers and Children, Kabul, Afghanistan

Full list of author information is available at the end of the article have imposed nationwide lockdown to tackle the disease spread that resulted in unconditional detrimental effect on international economy $[3,4]$.

Considering the clinical presentations, SARS-CoV2-associated disease has shown remarkable heterogeneity in its clinical presentation $[5,6]$. The wide spectrum of clinical features can be attributed to the fact that SARS-CoV-2 uses angiotensin II, the body's most abundant receptor protein, as a portal to enter the cell [7]. The symptoms range from mere loss of taste and/or smell sensation with mild cough, usually in young adults, to severe and frequently life-threatening acute respiratory original author(s) and the source, provide a link to the Creative Commons licence, and indicate if changes were made. The images or other third party material in this article are included in the article's Creative Commons licence, unless indicated otherwise in a credit line to the material. If material is not included in the article's Creative Commons licence and your intended use is not permitted by statutory regulation or exceeds the permitted use, you will need to obtain permission directly from the copyright holder. To view a copy of this licence, visit http://creativecommons.org/licenses/by/4.0/. The Creative Commons Public Domain Dedication waiver (http://creativeco mmons.org/publicdomain/zero/1.0/) applies to the data made available in this article, unless otherwise stated in a credit line to the data. 
distress syndrome, mostly in older individuals [8]. In the context of classic clinical picture, devastating cardiovascular events have claimed many precious lives with formation of intracardiac thrombus complicating to embolic events [9]. Similarly, myocardial dysfunction and heart failure have been reported in many confirmed cases of coronavirus disease 2019 (COVID-19), in patients with previously normal hemodynamic status $[10,11]$.

Patients who presented with gastrointestinal symptoms had variable symptoms; whereas some patients developed acute gastroenteritis, others developed fulminant liver dysfunction [12]. Transient elevation in transaminase enzymes was a frequent sign of the disease [12].

Neurological abnormalities have been quite frequent in patients affected by COVID-19, ranging from peripheral nerve dysfunction to life-threatening encephalitis [13]. Many institutions have reported cases of Guillain-Barre Syndrome (GBS) in association with COVID-19. We present a case of AMSAN, a rare and severe variant of GBS, that affected a patient during recovery from COVID-19.

\section{Case presentation}

A 61-year-old Afghan gentleman, businessman by profession, presented to a general practitioner with febrile illness associated with generalized body aches and pains, in early May 2020. He was a nonalcoholic and nonsmoker and had no significant past medical or surgical history. On examination, the patient was found to have normal oxygen saturation with normal physical examination findings. Thus, the patient was discharged home with paracetamol and was advised to maintain adequate hydration. During the first week of illness, the clinical progression was fairly controlled, but through the second and third weeks of illness, the patient developed malaise, loss of appetite, distaste, and loss of smell sensation. At that time, the patient's oxygen saturation was still within normal range with normal hydration status, and the patient was thus continued with the original management plan and was asked to visit hospital if there was any aggravation of symptoms. Through the fourth week of illness, there was aggravation of clinical features with frequent drops in oxygen saturation noted overnight and generalized weakness, and cramps especially in the lower limbs. By the end of the first month of illness, the patient was afebrile with resolution of most of the symptoms including improvement of appetite and return of sense of smell and taste, but the body aches and muscle weakness further aggravated. This was when serological tests were performed for SARS-CoV-2 that showed strong IgG positivity with negative reaction for IgM, presented in Table 2. The patient had normal D-dimer, elevated C-reactive protein $(23 \mathrm{mg} / \mathrm{L})$, normal liver enzymes, and normal renal profile.
Table 1 Muscle power scale before and after IVIG therapy

\begin{tabular}{lll}
\hline Muscle & $\begin{array}{l}\text { Power before IVIG } \\
\text { therapy }\end{array}$ & $\begin{array}{l}\text { Power 48 hours } \\
\text { after IVIG } \\
\text { therapy }\end{array}$ \\
\hline Shoulders & $1 / 5$ & $4 / 5$ \\
Wrists & $1 / 5$ & $4 / 5$ \\
Hips & $2 / 5$ & $4 / 5$ \\
Both knees & $2 / 5$ & $4 / 5$ \\
\hline
\end{tabular}

Table 2 Laboratory investigations performed at the time of hospital admission

\begin{tabular}{|c|c|c|c|}
\hline \multicolumn{4}{|l|}{ Laboratory investigations } \\
\hline Parameters & Values & Parameters & Values \\
\hline Complete blood count** & & Biochemistry** & \\
\hline $\mathrm{Hb}$ & $14.8 \mathrm{~g} / \mathrm{dL}$ & Liver function test ${ }^{* *}$ & \\
\hline HCT & $47.38 \%$ & & \\
\hline WBC & $16,900 / \mu \mathrm{L}$ & AST & $21 \mathrm{IU} / \mathrm{L}$ \\
\hline Neutrophil & $82 \%$ & & \\
\hline Lymphocyte & $11 \%$ & ALT & $11 \mathrm{IU} / \mathrm{L}$ \\
\hline Eosinophil & $0.5 \%$ & & \\
\hline Monocyte & $6 \%$ & Total bilirubin & $8 \mu \mathrm{mol} / \mathrm{L}$ \\
\hline Basophil & $0.5 \%$ & & \\
\hline ABG & & Direct bilirubin & $6.9 \mu \mathrm{mol} / \mathrm{L}$ \\
\hline $\mathrm{pH}$ & 7.21 & & \\
\hline $\mathrm{PCO}_{2}$ & $73 \mathrm{mmHg}$ & Indirect bilirubin & $2.1 \mu \mathrm{mol} / \mathrm{L}$ \\
\hline $\mathrm{PO}_{2}$ & $54 \mathrm{mmHg}$ & & \\
\hline $\mathrm{HCO}_{3}$ & $31 \mathrm{mmHg}$ & Renal function test** & \\
\hline $\mathrm{SPO}_{2}$ & $84 \%$ & BUN & $5 \mu \mathrm{mol} / \mathrm{L}$ \\
\hline COVID-19 serologic test* & & Creatinine & $72 \mu \mathrm{mol} / \mathrm{L}$ \\
\hline $\lg M$ & Negative & $\mathrm{HbA}_{1 c^{* *}}$ & $5.1 \%$ \\
\hline $\lg G$ & Positive & $\mathrm{FBS}^{* *}$ & $4.1 \mathrm{mmol} / \mathrm{L}$ \\
\hline
\end{tabular}

FBG fasting blood glucose, HBA1c hemoglobin A1C, CREAT serum creatinine, $B U N$ blood urea nitrogen, $A L T$ serum alanine aminotransferase, $A S T$ serum aspartate aminotransferase, TBILL total bilirubin, $C B C$ complete blood count, $H b$ hemoglobin, WBC total white blood cell count, $P L T$ platelet count, $N$ percentage of neutrophils, $L$ percentage of lymphocytes, $E$ percentage of eosinophils, $M$ percentage of monocytes, $\mathrm{PH}$ power of hydrogen ion concentration, $\mathrm{PCO}_{2}$ partial pressure of carbon dioxide in blood, $\mathrm{PO}_{2}$ partial pressure of oxygen in blood, $\mathrm{HCO}_{3}^{-}$bicarbonate ion concentration, $\mathrm{SPO}^{2}$ oxygen saturation

*The test was done at the end of the fourth week of disease.

**The test was done during the first week of the second month of disease, during the hospital admission

As presented in Table 1, in a span of 5 days, the patient's condition deteriorated with development of flaccidity in all of the upper and lower limb muscles, demonstrating $1 / 5$ power at shoulders and wrist joints on both sides and 2/5 power at hip and knee joints on both sides. Oxygen saturation also deteriorated with the lowest recorded value of $76 \%$ saturation. The laboratory workup revealed normal liver and renal 
profile with normal fasting blood glucose and blood counts, while arterial blood gas analysis revealed type II respiratory failure, as presented in Table 2 . Thus, the impression given by consultant neurologist was Guillain-Barre syndrome, and immediate nerve conduction studies were performed. The nerve conduction studies, as presented in Tables 3 and 4, revealed diffuse axonal sensory-motor polyneuropathy. Considering the clinical context, the impression was acute sensory-motor axonal neuropathy (AMSAN), a variant of GuillainBarre Syndrome (GBS). Accordingly, the patient was started on intravenous immunoglobulin (IVIG) with a dose of $400 \mathrm{mg}$ per kilogram body weight daily, for 5 days. Following the commencement of IVIG, there was significant clinical alleviation of symptoms with improvement in respiratory functions, oxygen saturation, and return of muscle power, recovering to $4 / 5$ power in the upper and lower limbs on both sides. Two weeks post IVIG therapy, with concomitant daily physiotherapy, the patient was able to be independent in active daily life, had muscle power of $5 / 5$ at all the joints, and continued to maintain good health at the second month and then 6 months after initial diagnosis of GBS. At the moment, 9 months after the initial presentation, the patient is absolutely normal.

\section{Discussion}

Guillain-Barre Syndrome (GBS) is an acute inflammatory polyradiculoneuropathy resulting in flaccid paralysis in affected muscles [14]. The signs and symptoms can range from proximal muscle weakness to life-threatening respiratory failure [15]. In our patient, COVID-19-related signs and symptoms evolved over a period of 4 weeks. Although by the end of the month there was resolution of all the symptoms, the patient rapidly progressed to develop GBS-related flaccid paralysis during the recovery phase of the disease with significant clinical improvement upon administration of IVIG. It is worth mentioning that our patient presented with AMSAN, the severe variant of GBS, complicating the recovery phase of COVID-19, which was so far not been reported in the literature.

According to an estimate, more than 100,000 people are affected by GBS every year, worldwide [14]. The pathophysiological mechanism involved in the development of GBS is complex, but complement-mediated injury to the myelin sheath of peripheral nerves was identified to be

Table 3 Motor nerve conduction studies

\begin{tabular}{|c|c|c|c|c|c|c|c|c|c|c|c|c|c|}
\hline \multirow[t]{2}{*}{$\begin{array}{l}\text { Nerve-muscle } \\
\text { stimulus site }\end{array}$} & \multirow[t]{2}{*}{ Stimulus site } & \multicolumn{2}{|c|}{$\begin{array}{l}\text { Latency } \\
\text { (milliseconds) }\end{array}$} & \multicolumn{2}{|c|}{ Distance $(\mathrm{cm})$} & \multicolumn{2}{|c|}{ Amplitude (mV) } & \multicolumn{2}{|c|}{$\mathrm{NCV}$ (m/second) } & \multicolumn{2}{|c|}{$\begin{array}{l}\text { F-LAT } \\
\text { (milliseconds) }\end{array}$} & \multicolumn{2}{|c|}{$\begin{array}{l}\text { Duration } \\
\text { (milliseconds) }\end{array}$} \\
\hline & & Right & Left & Right & Left & Right & Left & Right & Left & Right & Left & Right & Left \\
\hline Median-APB & Wrist & & 5.7 & & 7.0 & & 6.2 & & & & & & \\
\hline Median-APB & Elbow & & 9.8 & & 22.0 & & 5.6 & & 54.0 & & & & \\
\hline Ulnar-ADM & Wrist & & 3.3 & & 7.0 & & 6.2 & & & & 34.3 & & \\
\hline Ulnar-ADM & B.Elbow & & 7.5 & & 21.0 & & 5.5 & & 50.0 & & & & \\
\hline Ulnar-ADM & A.Elbow & & 9.3 & & 10.0 & & 4.9 & & 56.0 & & & & \\
\hline Tibial—AHL & Ankle & & 7.2 & & 10.0 & & 1.3 & & & & & & \\
\hline Tibial—AHL & Popliteal fossa & & 19.6 & & 40.0 & & 0.9 & & 32.0 & & & & \\
\hline Peroneal_EDB & Ankle & & 6.2 & & 7.0 & & 0.7 & & & & & & \\
\hline Peroneal_EDB & Fibula head & & 13.5 & & 29.0 & & 0.8 & & 40.0 & & & & \\
\hline Peroneal_EDB & Popliteal fossa & & 15.6 & & 8.0 & & 0.7 & & 38.0 & & & & \\
\hline
\end{tabular}

$A P B$ abductor pollicis brevis, $A D M$ abductor digiti minimi, $B . E l b o w$ below elbow, $A$.Elbow above elbow, $A H L$ abductor hallucis longus, EDB extensor digitorum brevis, $F 2$ finger 2, F5 finger 5, NR not recorded, NCV nerve conduction velocity

Table 4 Sensory nerve conduction studies

\begin{tabular}{|c|c|c|c|c|c|c|c|c|c|c|}
\hline \multirow[t]{2}{*}{ Nerve } & \multirow[t]{2}{*}{ Recording site } & \multirow[t]{2}{*}{ Stimulating site } & \multicolumn{2}{|c|}{ Latency (seconds) } & \multicolumn{2}{|c|}{ Distance $(\mathrm{cm})$} & \multicolumn{2}{|c|}{ Amplitude $(\mu \mathrm{V})$} & \multicolumn{2}{|c|}{$\begin{array}{l}\mathrm{NCV}(\mathrm{m} / \\
\text { second) }\end{array}$} \\
\hline & & & Right & Left & Right & Left & Right & Left & Right & Left \\
\hline Median & $\mathrm{F} 2$ & Wrist & & NR & & 13.0 & & NR & & NR \\
\hline Ulnar & F5 & Wrist & & NR & & 11.0 & & NR & & NR \\
\hline Sural & Ankle & Calf & & NR & & 14.0 & & NR & & NR \\
\hline
\end{tabular}


the most common mechanism [16]. Complement-fixing anti-glycolipid autoantibodies target the nodes of Ranvier, which is the principle target in GBS [16]. Although such autoantibodies are the most pathogenic factors in the development of GBS, one-third of patients with GBS demonstrate no evidence of antibody development [17, 18].

GBS is triggered by a prior infection that initiates the pathogenic cross-reactive immune response, mostly in the form of autoantibodies [16, 20]. Infection by Campylobacter jejuni, cytomegalovirus, Epstein-Barr virus, and Mycoplasma pneumoniae are commonly identified triggering pathogens [16]. Other viruses that may be complicated with GBS include Zika virus and influenza virus $[19,20]$. Since the start of the COVID-19 pandemic, many cases of GBS have been reported to be associated with the disease [21].

Variable pathophysiological mechanisms are involved behind different variants of GBS [22]. In the acute motor axonal neuropathy (AMAN) form of GBS, the infecting organisms probably share homologous epitopes with the proteins in peripheral nerves, and therefore, the antibodies produced during infection cross-react with the nerves, causing axonal degeneration [17]. Proposed target molecules in AMAN are likely to be gangliosides expressed on the membrane of motor nerve axons [17]. In the acute inflammatory demyelinating polyneuropathy (AIDP) variant of GBS in which the exact molecular mechanism is not yet understood, the immune system reacts against target epitopes in Schwann cells resulting in demyelination $[17,23]$.

In acute motor-sensory axonal polyneuropathy (AMSAN), the pathophysiology is similar to that in AMAN, with the target proteins being located on sensory and motor neuronal axons $[17,22]$. The pathophysiological mechanism behind the occurrence of GBS in patients post COVID19-related disease could be multifactorial, and depend upon the variant of GBS that would manifest in the affected patient.

GBS classically presents with sensory impairment followed by generalized weakness that develops over several days. In most of the affected patients, it leads to quadriparesis [24]. Approximately two-thirds of patients report upper or lower respiratory tract infection or gastrointestinal illness preceding the development of GBS-associated symptoms [24]. Similarly, up to one-third of patients require intubation and ventilation because of respiratory failure [24]. Our patient rapidly deteriorated during the COVID-19 recovery phase, manifesting with flaccid paralysis including oxygen desaturation due to involvement of respiratory muscles.

In most patients, thorough neurological examination often leads to the suspicion of GBS, as was the case with our patient. Routine biochemical analyses are followed by more revealing diagnostic workup such as cerebrospinal fluid analysis and, most importantly, the neurophysiological assessments that lead towards the diagnosis [15]. Electrodiagnostic studies are not required to diagnose GBS, but they are helpful in establishing the diagnosis, especially in cases that present with atypical features [25]. Typically the electrophysiological studies in GBS reveal sensorimotor polyradiculoneuropathy or polyneuropathy, indicated by reduced conduction velocities, reduced sensory and motor evoked amplitudes, abnormal temporal dispersion, and/or partial motor conduction blocks [25]. A characteristic feature identified by nerve conduction studies is a "sural sparing pattern" in which the sural sensory nerve action potential, primarily in its amplitude, is normal while the amplitude of median and ulnar sensory nerve action potentials is abnormal or even absent [25]. In our patient, while the disease had already entered the recovery phase, symptoms such as proximal muscle weakness and unexplained drop in oxygen saturation led to the suspicion of GBS that was confirmed by electrophysiological studies.

Conventionally, therapeutic options include plasmapheresis, IVIG, in stable patients, while mechanical ventilation is required in patients who develop respiratory failure due to involvement of respiratory muscles [22]. In Afghanistan, healthcare establishments with mechanical ventilator support are rarely available. Similarly, there is no institution to provide plasma exchange services. Therefore, the only option left was IVIG with early commencement of physiotherapy, which had a dramatic effect, resulting in complete resolution of symptoms in a matter of days. This is one of the main reasons our case is being reported, that is, to inform doctors, especially firstline physicians, about this particular complication and thus have lower threshold in initiating the initial screening workup for GBS, including thorough neurological examination.

\section{Conclusion}

In our case report, we presented the rare and most severe variant of GBS, AMSAN, that complicated COVID19-related disease in its recovery phase. To our knowledge, this was the first case of AMSAN complicating COVID-19. Clinical suspicion and prompt diagnosis led to early intervention, leading to complete recovery. While the world is entering the second wave of COVID-19, clinicians, particularly who manage old-age individuals, need to have insight into this dreadful but manageable complication of COVID-19-related disease. 


\begin{abstract}
Abbreviations
GBS: Guillain-Barre syndrome; AMAN: Acute motor axonal polyneuropathy; AMSAN: Acute motor-sensory axonal polyneuropathy; AIDP: Acute inflammatory demyelinating polyneuropathy; COVID19: Coronavirus disease 2019; FBG: Fasting blood glucose; HBA1c: Hemoglobin A1c; CREAT: Serum creatinine; BUN: Blood urea nitrogen; ALT: Serum alanine aminotransferase; AST: Serum aspartate aminotransferase; TBILL: Total bilirubin; CBC: Complete blood count; Hb: Hemoglobin; WBC: Total white blood cell count; PLT: Platelet count; PH: Power of hydrogen ion concentration; $\mathrm{PCO}_{2}$ : Partial pressure of carbon dioxide in blood; $\mathrm{PO}_{2}$ : Partial pressure of oxygen in blood; $\mathrm{HCO}_{3}$ : Bicarbonate ion concentration; $\mathrm{SPO}^{2}$ : Oxygen saturation; $\mathrm{APB}$ : Abductor pollicis brevis; $\mathrm{ADM}$ : Abductor digiti minimi; B.Elbow: Below elbow; A.Elbow: Above elbow; AHL: Abductor hallucis longus; EDB: Extensor digitorum brevis; F2: Finger 2; F5: Finger 5; NR: Not recorded; NCV: Nerve conduction velocity.
\end{abstract}

\section{Acknowledgements}

We would like to extend our sincere gratitude to all our laboratory technologists and nursing staff for their tireless efforts towards patient care, during the COVID-19 pandemic

\section{Authors' contributions}

SRN, AMH, TWB, and ESH conceived the idea. ESH, AMH, and SRN were the major contributors to the writing of the manuscript. $\mathrm{AMH}, \mathrm{HRH}$, and ESH diagnosed the case. HAZ, FNE and MA performed biochemical tests. ESH, GAT, and $\mathrm{HRH}$ performed and interpreted the nerve conduction studies. SRN, AMH, and SOR were the major contributors for critically revising the manuscript for important intellectual content. SRN, AMH, RMS, ESE, and HAM have given expert opinion and final approval of the version to be published. All authors read and approved the final manuscript.

\section{Funding}

The authors received no funding for the writing.

Availability of data and materials

All the generated data are included in this article.

\section{Declarations}

\section{Ethical approval and consent to participate}

Not applicable.

\section{Consent for publication}

Written informed consent was obtained from the patient for the publication of this case report and any accompanying images. A copy of the written consent is available for review by the Editor-in-Chief of this journal.

\section{Competing interests}

The authors declare that they have no competing interests.

\section{Author details}

'Department of Pathology and Laboratory Medicine, French medical Institute for Mothers and Children, Kabul, Afghanistan. ${ }^{2}$ Department of Medicine, Jumhoriat Hospital, Afghan Ministry of Health, Kabul, Afghanistan. ${ }^{3}$ Neurology Unit, Department of Medicine, French Medical Institute for Mothers and Children, Kabul, Afghanistan. ${ }^{4}$ Department of Quality, French Medical Institute for Mothers and Children, Kabul, Afghanistan.

Received: 23 November 2020 Accepted: 28 June 2021

Published online: 16 July 2021

\section{References}

1. Landry MD, Geddes L, Park Moseman A, Lefler JP, Raman SR, van Wijchen J. Early reflection on the global impact of COVID19, and implications for physiotherapy. Physiotherapy. 2020;107:A1-3. https://doi.org/10.1016/j. physio.2020.03.003 (Epub 2020 Mar 20. PMID: 32312528; PMCID: PMC7194933)

2. Gopalan HS, Misra A. COVID-19 pandemic and challenges for socio-economic issues, healthcare and National Health Programs in India. Diabetes
Metab Syndr. 2020;14(5):757-9. https://doi.org/10.1016/j.dsx.2020.05. 041 (Erratum in: Diabetes Metab Syndr. 2021 Jan-Feb;15(1):467-468. PMID: 32504992; PMCID: PMC7261093).

3. Hevia C, Neumeyer A. "La tormenta perfecta: el COVID-19 en las economías emergentes", International Development Policy, Revue internationale de politique de développement [Online], 12.2. 2020. https:// doi.org/10.4000/poldev.3457 (connection on 07 July 2021. URL:http:// journals.openedition.org/poldev/3457)

4. Simon J, Helter TM, White RG, et al. Impacts of the Covid-19 lockdown and relevant vulnerabilities on capability well-being, mental health and social support: an Austrian survey study. BMC Public Health. 2021;21:314. https://doi.org/10.1186/s12889-021-10351-5.

5. Singhal T. A review of coronavirus disease-2019 (COVID-19). Indian J Pediatr. 2020;87:281-6. https://doi.org/10.1007/s12098-020-03263-6.

6. Guo YR, Cao QD, Hong ZS, et al. The origin, transmission and clinical therapies on coronavirus disease 2019 (COVID-19) outbreak -an update on the status. Military Med Res. 2020;7:11. https://doi.org/10.1186/ s40779-020-00240-0.

7. Kim JH, Baek YH, Lee H, Choe YJ, Shin HJ, Shin JY. Clinical outcomes of COVID-19 following the use of angiotensin-converting enzyme inhibitors or angiotensin-receptor blockers among patients with hypertension in Korea: a nationwide study. Epidemiol Health. 2021;43:e2021004. https:// doi.org/10.4178/epih.e2021004 (Epub 2020 Dec 29. PMID: 33445824; PMCID: PMC7973148).

8. Koh J, Shah SU, Chua P, Gui H, Pang J. Epidemiological and clinical characteristics of cases during the early phase of COVID-19 pandemic: a systematic review and meta-analysis. Front Med. 2020;7:295. https://doi. org/10.3389/fmed.2020.00295.

9. Janus SE, Hajjari J, Cunningham MJ, Hoit BD. COVID19: a case report of thrombus in transit. Eur Hear J Case Reports. 2020;4(FI1):1-4. https://doi. org/10.1093/ehjcr/ytaa189.

10. Bertoncelli D, Guidarini M, Della Greca A, Ratti C, Falcinella F, lovane B, Dutto ML, Caffarelli C, Tchana B. COVID19: potential cardiovascular issues in pediatric patients. Acta Biomed. 2020;91(2):177-83. https://doi.org/10. 23750/abm.v91i2.9655 (PMID:32420942;PMCID:PMC7569665).

11. Kishor K, Marwah R, Anantharaj A, Kalra S. Cardiovigilance in COVID 19. J Pak Med Assoc. 2020;70(5):S77-80. https://doi.org/10.5455/JPMA.14 (PMID: 32515382)

12. Sanz Segura P, Arguedas Lázaro Y, Mostacero Tapia S, Cabrera Chaves T, Sebastián Domingo JJ. Involvement of the digestive system in COVID-19. A review. Gastroenterol Hepatol. 2020;43(8):464-71. https://doi.org/10. 1016/.j.gastrohep.2020.06.004

13. Makda A, Kumar S, Kumar A, Kumar V, Rizwan A. The frequency of neurological symptoms in COVID-19 patients at a tertiary care hospital in Pakistan. Cureus. 2020;12(9):e10360. https://doi.org/10.7759/cureus. 10360 (PMID: 33062483; PMCID: PMC7549861).

14. Willison HJ, Jacobs BC, van Doorn PA. Guillain-Barré syndrome. Lancet. 2016;388(10045):717-27. https://doi.org/10.1016/S0140-6736(16)00339-1 (Epub 2016 Mar 2. PMID: 26948435).

15. Malek E, Salameh J. Guillain-Barre Syndrome. Semin Neurol. 2019;39(5):589-95. https://doi.org/10.1055/s-0039-1693005 (Epub 2019 Oct 22 PMID: 31639842).

16. Kaida K. Guillain-Barré Syndrome. Adv Exp Med Biol. 2019:1190:323-31. https://doi.org/10.1007/978-981-32-9636-7_20 (PMID: 31760653).

17. Goodfellow JA, Willison HJ. Guillain-Barré syndrome: a century of progress. Nat Rev Neurol. 2016;12(12):723-31. https://doi.org/10.1038/nrneu rol.2016.172 (Epub 2016 Nov 18. PMID: 27857121).

18. Van Den Berg B, Walgaard C, Drenthen J, Fokke C, Jacobs BC, Van Doorn PA. Guillain-Barré syndrome: Pathogenesis, diagnosis, treatment and prognosis. Nat Rev Neurol. 2014;10(8):469-82. https://doi.org/10.1038/ nrneurol.2014.121 (Epub 2014 Jul 15. PMID: 25023340).

19. Cao-Lormeau VM, Blake A, Mons S, Lastère S, Roche C, Vanhomwegen J, Dub T, Baudouin L, Teissier A, Larre P, Vial AL, Decam C, Choumet V, Halstead SK, Willison HJ, Musset L, Manuguerra JC, Despres P, Fournier E, Mallet HP, Musso D, Fontanet A, Neil J, Guillain-Barré Ghawché F. GuillainBarré Syndrome outbreak associated with Zika virus infection in French Polynesia: a case-control study. Lancet. 2016;387(10027):1531-9. https:// doi.org/10.1016/S0140-6736(16)00562-6 (Epub 2016 Mar 2. PMID: 26948433; PMCID: PMC5444521).

20. Lehmann HC, Hartung HP, Kieseier BC, Hughes RAC. Guillain-Barré syndrome after exposure to influenza virus. Lancet Infect Dis. 
2010;10(9):643-51. https://doi.org/10.1016/S1473-3099(10)70140-7 (PMID: 20797646).

21. Wada S, Nagasaki Y, Arimizu Y, Shimo M, Matsukuma Y, Okamoto M, Yoshida S, Ohashi I, Hashimoto G, Kuwashiro T, Yasaka M, Okada Y. Neurological disorders identified during treatment of a SARS-COV-2 infection. Intern Med. 2020;59(17):2187-9. https://doi.org/10.2169/inter nalmedicine.5447-20 (Epub 2020 Jul 21. PMID: 32713924; PMCID: PMC7516316)

22. Wijdicks EFM, Klein CJ. Guillain-Barré Syndrome. Mayo Clinic Proceedings. 2017;92(3):467-79. https://doi.org/10.1016/j.mayocp.2016.12.002 (PMID: 28259232).

23. Dimachkie MM, Barohn RJ. Guillain-Barré syndrome and variants. Neurologic Clinics. 2013;31(2):491-510. https://doi.org/10.1016/j.ncl.2013.01. 005 (Epub 2013 Feb 19. PMID: 23642721; PMCID: PMC3939842)

24. Donofrio PD. Guillain-Barré Syndrome. Continuum (Minneap Minn). 2017;23(5):1295-309. https://doi.org/10.1212/CON.0000000000000513 (PMID: 28968363).
25. Leonhard SE, Mandarakas MR, Gondim FAA, Bateman K, Ferreira MLB, Cornblath DR, van Doorn PA, Dourado ME, Hughes RAC, Islam B, Kusunoki S, Pardo CA, Reisin R, Sejvar JJ, Shahrizaila N, Soares C, Umapathi T, Wang Y, Yiu EM, Willison HJ, Jacobs BC. Diagnosis and management of Guillain-Barré syndrome in ten steps. Nat Rev Neurol. 2019;15(11):671-83. https://doi.org/10.1038/s41582-019-0250-9 (Epub 2019 Sep 20. PMID:31541214; PMCID: PMC6821638).

\section{Publisher's Note}

Springer Nature remains neutral with regard to jurisdictional claims in published maps and institutional affiliations.
Ready to submit your research? Choose BMC and benefit from:

- fast, convenient online submission

- thorough peer review by experienced researchers in your field

- rapid publication on acceptance

- support for research data, including large and complex data types

- gold Open Access which fosters wider collaboration and increased citations

- maximum visibility for your research: over 100M website views per year

At BMC, research is always in progress.

Learn more biomedcentral.com/submissions 